\title{
Inhibition of corrosion of mild steel pipeline carrying simulated oil well water by Allium sativum (garlic) extract
}

\author{
S.C. Joycee, ${ }^{1,2}$ A.S. Raja, ${ }^{2}$ A.S. Amalraj ${ }^{3}$ and S. Rajendran ${ }^{1}\left[{ }^{*} *\right.$ \\ ${ }^{1}$ Department of Chemistry, Corrosion Research Centre, St. Antony's College of Arts and \\ Sciences for Women, Dindigul-624 005, India \\ ${ }^{2}$ Department of Chemistry, G.T.N Arts College (Autonomous), Dindigul-624 005, India \\ ${ }^{3}$ Department of Physics, Sree Sevugan Annamalai College, Devakottai-630 303, India \\ *E-mail: susairajendran@gmail.com
}

\begin{abstract}
The inhibiting effect of Allium sativum in controlling corrosion of mild steel in simulated oil well water (SOWW) in the absence and presence of $\mathrm{Zn}^{2+}$ has been investigated by different techniques like weight loss method, potentiodynamic polarization and electrochemical impedance spectroscopy for different concentrations of the plant extract. The formulation consisting of $10 \mathrm{~mL}$ of (10\% aqueous extract) Allium sativum (garlic extract) and $50 \mathrm{ppm}$ of $\mathrm{Zn}^{2+}$ provides $87 \%$ of inhibition efficiency. The results indicate that the corrosion inhibition efficiency increased on increasing plant extract concentration. The inhibitor system was found to be a cathodic inhibitor with the optimum inhibition concentration of $10 \mathrm{~mL}$ of Allium sativum and $50 \mathrm{ppm}$ of $\mathrm{Zn}^{2+}$ in potentiodynamic polarization study. The corrosion potential is shifted from $-777 \mathrm{mV} v s$. SCE to $-880 \mathrm{mV} v s$. SCE. The linear polarization resistance (LPR) value increases from $482 \mathrm{Ohm} \cdot \mathrm{cm}^{2}$ to $1831 \mathrm{Ohm} \cdot \mathrm{cm}^{2}$. The corrosion current decreases from $1.034 \times 10^{-4} \mathrm{~A} / \mathrm{cm}^{2}$ to $0.1515 \times 10^{-4} \mathrm{~A} / \mathrm{cm}^{2}$. These factors confirm that the Allium sativum controls the corrosion of mild steel in SOWW. The AC impedance spectra confirm that the protective coating is very stable as revealed by the fact that in the presence of inhibitor on mild steel, the charge transfer resistance increases, impedance increases, whereas double layer capacitance decreases to a great extent. Surface analysis has been carried out to find out the surface morphology of the mild steel in the presence and absence of the inhibitor. The obtained results show that the Allium sativum extract acts as a good inhibitor for the corrosion of mild steel in SOWW.
\end{abstract}

Received: June 12, 2021. Published: July 23, 2021

doi: $\underline{10.17675 / 2305-6894-2021-10-3-8}$

Keywords: Allium sativum, corrosion inhibitor, simulated oil well water, polarisation study and AC impedance spectra, AFM.

\section{Introduction}

Failure of equipment due to corrosion is a main problem in the chemical and petrochemical industry [1]. Mild steel is still the material most commonly used for pipes and other equipment parts. Mild steel pipes are widely used in oil transportation, and in their ways from oil fields to petroleum refineries passes across different environments. Many 
parameters and environmental factors influence the corrosion of pipe materials, such as, temperature, $\mathrm{pH}$, salinity, etc., These factors play an important role in corrosion of construction materials. Corrosion can be minimized by changing the environmental factors that sometimes hard to control, or by deal with pipe itself [2].

Mild steel corrodes quite easily due to the ability of all common structural metals to form surface oxide films when exposed to pure air; but the oxide formed on mild steel is readily broken down, and it is not repaired in the presence of moisture. Mild steel $(\mathrm{Fe})$ undergoes a spontaneous reaction with air $\left(\mathrm{O}_{2}\right)$ and moisture $\left(\mathrm{H}_{2} \mathrm{O}\right)$ to form an often insoluble and usually non-protective reddish brown hydrated ferric oxide known as brown rust [3]. This complex process is simplified by the chemical equation shown below:

$$
4 \mathrm{Fe}_{(\mathrm{s})}+2 \mathrm{H}_{2} \mathrm{O}_{(\mathrm{l})}+3 \mathrm{O}_{2(\mathrm{~g})} \rightarrow 2 \mathrm{Fe}_{2} \mathrm{O}_{3} \cdot \mathrm{H}_{2} \mathrm{O}_{(\mathrm{s})}
$$

Use of inhibitors is one of the most practical methods for protection against corrosion to prevent metal dissolution. Corrosion inhibitors have been widely studied in many industries to reduce the corrosion rate of metal surfaces in contact with aggressive medium [4].

Plant extracts are viewed as environmentally friendly and ecologically acceptable inhibitors. Plant products are low cost, readily available, and renewable sources of materials. The extract from their leaves, barks, seeds, fruits, and roots comprise of mixtures of organic compounds containing nitrogen, sulphur, and oxygen atoms and some [5] have been reported to function as effective inhibitors of metal corrosion in different aggressive environments. Generally, the inhibitive effect of plant extract is attributed to the adsorption of organic substances on the metal surface, blocking active sites or even forming a protective barrier. So, in the recent years, researches have been directed towards the search of green corrosion inhibitors. The plant extract(s) can be called as "green (corrosion) inhibitors" since the use of plant extracts are not only eco-friendly but also economical, renewable and readily available sources.

Jyothi et al. [6] have reviewed the use of green inhibitors. Rajendran et al. [7] have explained green solution to corrosion problems and also discussed the various methods employed in this field. The list of references reported here mainly focused the use of plant extracts as green corrosion inhibitors for mild steel [8-10].

Allium sativum is of the Genus Onions, Class: Equisetopsida, in the family of Amaryllidaceae. However, garlic contains nearly three times as much sulphur-containing compound as onions. The mature, intact Alliums contain mainly cysteine sulphoxides, and when tissues are chopped, the enzyme allinase is released, converting the cysteine sulphoxides into the thiosulphinates [11]. Evidence from several investigations suggests that the biological and medical functions of garlic are mainly due to their high organo-sulphur compounds content. The primary sulphur-containing constituents in garlic are the $S$ alk(en)yl- $L$-cysteine sulphoxides (ACSOs), such as allicin, and $g$-glutamylcysteines, Allicin (diallylthiosulenate) [12]. 
However, the use of garlic extract as corrosion inhibitor is limited in the literature. Thus, Rajam et al. [13], used garlic for the corrosion inhibition of carbon steel in well water in the presence and absence of $\mathrm{Zn}^{2+}$ and found that $2 \mathrm{~mL}$ of garlic extract and $25 \mathrm{ppm}$ of $\mathrm{Zn}^{2+}$ offered a $70 \%$ of inhibition efficiency. In another works $[13,14]$ the same authors added Malic acid to the Garlic extract $+\mathrm{Zn}^{2+}$ system, and increasing the inhibition efficiency, but found that it decreased as time elapsed or decreasing the $\mathrm{pH}$ value of the solution.

The present work is undertaken:

(i) to evaluate the inhibition efficiency (IE) of an aqueous extract of garlic in controlling the corrosion of mild steel in simulated oil well water in the absence and presence of $\mathrm{Zn}^{2+}$,

(ii) to analyze the protective film formed on the mild steel by FTIR spectra,

(iii) to understand the mechanistic aspects of corrosion inhibition by potentiodynamic polarization study, and

(iv) to propose a suitable mechanism for corrosion inhibition.

\section{Experimental}

Preparation of the specimens

The composition of mild steel specimen is given in Table 1.

Table 1. Composition of mild steel.

\begin{tabular}{cccccc}
\hline Name & Average \% & Abs. Std. Dev & Ref. Std. Dev & $\mathbf{1}$ & $\mathbf{2}$ \\
\hline $\mathrm{C}$ & 0.101 & 0.0014 & 1.4 & 0.102 & 0.1 \\
$\mathrm{Si}$ & 0.055 & 0.0021 & 3.89 & 0.053 & 0.056 \\
$\mathrm{Mn}$ & 1.629 & 0.0057 & 0.35 & 1.633 & 1.625 \\
$\mathrm{P}$ & 0.0087 & 0.0003 & 3.25 & 0.0085 & 0.0089 \\
$\mathrm{~S}$ & 0.0028 & 0.0003 & 10.1 & 0.0026 & 0.003 \\
$\mathrm{Cr}$ & 0.036 & 0.0014 & 3.93 & 0.037 & 0.035 \\
$\mathrm{Mo}$ & 0.0086 & 0.00007 & 0.83 & 0.0086 & 0.0085 \\
$\mathrm{Ni}$ & 0.033 & 0.0007 & 2.18 & 0.033 & 0.32 \\
$\mathrm{Cu}$ & 0.0063 & 0.00007 & 1.13 & 0.0062 & 0.0063 \\
$\mathrm{Al}$ & 0.044 & 0.0014 & 3.21 & 0.043 & 0.045 \\
$\mathrm{As}$ & 0.0011 & 0 & 0 & 0.0011 & 0.011 \\
$\mathrm{~B}$ & 0.0027 & 0.0005 & 18.68 & $<0.00010$ & $<0.00010$ \\
$\mathrm{Bi}$ & $<0.00010$ & 0.00002 & 84.85 & $<0.0025$ & 0.003 \\
$\mathrm{Ce}$ & 0.0032 & 0.0013 & 42.65 & 0.0041 & 0.0022 \\
\hline
\end{tabular}




\begin{tabular}{cccccc}
\hline Name & Average \% & Abs. Std. Dev & Ref. Std. Dev & $\mathbf{1}$ & $\mathbf{2}$ \\
\hline $\mathrm{Co}$ & 0.011 & 0 & 0 & 0.011 & 0.011 \\
$\mathrm{Mg}$ & 0.0003 & 0 & 0 & 0.0003 & 0.0003 \\
$\mathrm{Nb}$ & 0.03 & 0.0007 & 2.4 & 0.029 & 0.03 \\
$\mathrm{~Pb}$ & 0.0081 & 0.0013 & 15.71 & 0.0072 & 0.009 \\
$\mathrm{Sb}$ & 0.004 & 0.0004 & 8.95 & 0.0037 & 0.0042 \\
$\mathrm{Sn}$ & 0.0034 & 0 & 0 & 0.0034 & 0.0034 \\
$\mathrm{Ta}$ & 0.03 & 0.0071 & 23.57 & 0.025 & 0.035 \\
$\mathrm{La}$ & 0.0071 & 0 & 0 & 0.0071 & 0.0071 \\
$\mathrm{Ti}$ & 0.0035 & 0 & 0 & 0.0035 & 0.0035 \\
$\mathrm{~V}$ & 0.138 & 0.0014 & 1.02 & 0.137 & 0.139 \\
$\mathrm{~W}$ & 0.071 & 0,0078 & 11.03 & 0.076 & 0.065 \\
$\mathrm{Zn}$ & 0.0024 & 0 & 0 & 0.0024 & 0.0024 \\
$\mathrm{Zr}$ & 0.0051 & 0.0002 & 0.2 & 0.0052 & 0.0049 \\
$\mathrm{Se}$ & $<0.0005$ & 0.0001 & 4.42 & $<0.0005$ & $<0.0005$ \\
$\mathrm{~N}$ & 0.0093 & 0.00007 & 0.76 & 0.0092 & 0.0093 \\
$\mathrm{Ca}$ & 0.0014 & 0.0001 & 10.1 & 0.0013 & 0.0015 \\
$\mathrm{Te}$ & 0.0026 & 0.0025 & 97.91 & $<0.0010$ & 0.0044 \\
$\mathrm{Fe}$ & 97.74 & 0 & 0 & 97.74 & 97.74 \\
\hline & & & & & \\
\hline
\end{tabular}

Specimens of dimension $4.0 \mathrm{~cm} \times 1.0 \mathrm{~cm} \times 0.2 \mathrm{~cm}$ were used for weight loss method. For electrochemical studies, the specimens were embedded in epoxy resin leaving a working area of $1 \mathrm{~cm}^{2}$. The surface preparation of the mechanically abraded specimens was carried out using different grades of silicon carbide emery paper (up to 1200 grit) and subsequent cleaning with acetone and rinsing with double-distilled water were done before each experiment.

\section{Preparation of Allium sativum /garlic extract}

Allium sativum is dried well in the absence of sunlight. $10 \mathrm{~g}$ of Allium sativum is taken and boiled with distilled water. The solution is filtered and the filtrate is made up to $100 \mathrm{~mL}$. This is used as corrosion inhibitor in the present study.

\section{Preparation of simulated oil well water solution}

Simulated oil well water was prepared according to the procedure described by Azghandi et al. [15] by dissolving $3.5 \mathrm{~g}$ sodium chloride, $0.305 \mathrm{~g}$ of anhydrous calcium chloride and $0.186 \mathrm{~g}$ of magnesium chloride in double distilled water and making up to in a $100 \mathrm{~mL}$ in 
standard measuring flask (SMF). Just before the experiment add sodium sulphide $0.067 \mathrm{~g}$ and $0.4 \mathrm{~mL}$ of concentrated hydrochloric acid solution and test the smell. $100 \mathrm{ppm}$ of hydrogen sulphide gas is present in the solution. All chemicals used in this study were of AR grade and were obtained from Sigma-Aldrich and used as received. Now simulated oil well water is ready for use.

\section{Weight-loss method}

A very simple weight loss method was used for the determination of corrosion rate. The corrosion of mild steel in Allium sativum extract was investigated at room temperature using weight loss measurements. Mild steel specimens were immersed in $100 \mathrm{~mL}$ of the SOWW containing various concentrations of the inhibitor (garlic extract) in the absence and presence of $\mathrm{Zn}^{2+}$ for one day. The weight of the specimen before and after immersion was determined using a Digital Balance (Model AY 60 SHIMADZU). The corrosion rate $(C R)$ in mdd was calculated using the equation given below [16].

$$
\text { Corrosion rate }=W / A T
$$

Where, mdd is corrosion rate expressed in terms of metal loss $(\mathrm{mg})$ per decimetre square area per day, $W=$ weight loss in milligrams, $A=$ surface area of steel $\left(\mathrm{dm}^{2}\right), T=$ time of exposure in days. The inhibition efficiency (\%IE) was calculated using equation (3) [17].

$$
\% I E=\left[\left(w_{1}-w_{2}\right) / w_{1}\right] \cdot 100
$$

where $w_{1}$ and $w_{2}$ are the corrosion rates in the absence and presence of the inhibitor respectively.

\section{Potentiodynamic polarization study}

Polarization study was carried out in a $\mathrm{CHI}$ - electrochemical workstation impedance analyzer Model 660A using a three electrode cell assembly. Mild steel was used as working electrode, platinum as counter electrode and saturated calomel electrode (SCE) as reference electrode. From the polarization study, corrosion parameters such as linear polarization resistance (LPR), corrosion potential $E_{\text {corr }}$, corrosion current $I_{\text {corr }}$ and Tafel slopes ( $b_{\mathrm{a}}$ and $b_{\mathrm{c}}$ ) were measured $[18,19]$.

\section{Alternating current impedance spectra}

AC impedance spectra were recorded in the same instrument used for polarization study, using the same type of three electrode cell assembly. The real part $(Z)$ and imaginary part $(-Z)$ of the cell impedance were measured in Ohms for various frequencies. From Nyquist plot the values of charge transfer resistance $\left(R_{\mathrm{t}}\right)$ and double layer capacitance $\left(C_{\mathrm{dl}}\right)$ values were calculated. 


\section{Fourier Transform Infrared (FTIR) Spectroscopy}

The functional groups present in Allium sativum and the film formed on the metal surface were determined using the PerkinElmer 1600 Fourier transform infra-red spectrophotometer. The analysis was carried out by scanning the sample through a wave number range of 400 to $4000 \mathrm{~cm}^{-1}$.

\section{Scanning Electron Microscopic Studies (SEM)}

The mild steel immersed in SOWW (blank) solution and in the Allium sativum solution for a period of one day was removed, rinsed with double-distilled water, dried and observed in a scanning electron microscope to examine the surface morphology. The surface morphology measurements of mild steel were examined using JEOL MODEL6390 computer-controlled scanning electron microscope.

\section{Atomic Force of Microscopy}

The mild steel specimens were immersed in blank and in the Allium sativum solution for a period of one day. The specimens were rinsed with double distilled water, dried and subjected to the surface examination. Atomic force microscopy (Veeco Innova model) was used to observe the samples surface in tapping model, using cantilever with linear tips. The scanning area in the images was $10 \mu \mathrm{m} \times 10 \mu \mathrm{m}$ and the scan rate was $1 \mu \mathrm{m} / \mathrm{s}$.

\section{Results and Discussion}

\section{Analysis of Weight loss Study}

The results obtained from the gravimetric experiment performed with the different concentrations of the Allium sativum extract used as the inhibitor in $100 \mathrm{~mL}$ SOWW in the presence and absence of $\mathrm{Zn}^{2+}$ are measured and results are given in Table 2. In the presence of $\mathrm{Zn}^{2+}(50 \mathrm{ppm})$, excellent inhibitive property is shown by garlic extract. For example $10 \mathrm{~mL}$ of Allium sativum has only 53\% IE and $50 \mathrm{ppm}$ of $\mathrm{Zn}^{2+}$ has $12 \%$ IE but interestingly their combination has $87 \%$ IE. This is due to synergism existing between Allium sativum + $\mathrm{Zn}^{2+}$. The anodic reaction controlled by the formation of $\mathrm{Fe}^{2+}-$ Allicin complex formed on the anodic sides of the metal surface. The cathodic reaction is controlled by the formation of $\mathrm{Zn}(\mathrm{OH})_{2}$ on the cathodic sides of the metal surface. Thus both the anodic reaction (formation of $\mathrm{Fe}^{2+}$ ) and cathodic reaction (formation of $\mathrm{OH}^{-}$) are controlled by the inhibitor system consisting of Allium sativum extract and $\mathrm{Zn}^{2+}$ [20]. When $\mathrm{Zn}^{2+}$ added to Allium sativum extract, $\mathrm{Zn}^{2+}-$ Allicin complex is formed in solution. When mild steel is introduced in to this solution, $\mathrm{Fe}^{2+}-$ Allicin complex is formed on the metal surface. Now $\mathrm{Zn}^{2+}$ is released.

$$
\mathrm{Zn}^{2+}-\text { Allicin complex }+\mathrm{Fe}^{2+} \rightarrow \mathrm{Fe}^{2+}-\text { Allicin complex }+\mathrm{Zn}^{2+}
$$

$\mathrm{Fe}^{2+}-$ Allicin complex is more stable than $\mathrm{Zn}^{2+}-$ Allicin complex. The released $\mathrm{Zn}^{2+}$ combines with $\mathrm{OH}^{-}$to give insoluble $\mathrm{Zn}(\mathrm{OH})_{2}$ on the cathodic sites of the metal surface. 


$$
\mathrm{Zn}^{2+}+2 \mathrm{OH}^{-} \rightarrow \mathrm{Zn}(\mathrm{OH})_{2} \downarrow
$$

The $\mathrm{Zn}^{2+}-$ Allicin complex bond is strong enough to carry the $\mathrm{Zn}^{2+}-$ Allicin complex from the bulk of the solution towards the metal surface, and weak enough to break in presence of $\mathrm{Fe}^{2+}$ ion and to form $\mathrm{Fe}^{2+}-$ Allicin complex on the metal surface.

Table 2. Weight loss method (Gravimetric) data of mild steel in SOWW with and without inhibitor $-\mathrm{Zn}^{2+}$ system

\begin{tabular}{ccccc}
\hline \multirow{2}{*}{ Extract $(\mathbf{m l})$} & \multicolumn{2}{c}{$\mathbf{Z n}^{2+}(\mathbf{0}) \mathbf{p p m}$} & \multicolumn{2}{c}{$\mathbf{Z n}^{2+}(\mathbf{5 0}) \mathbf{p p m}$} \\
\cline { 2 - 5 } & $\boldsymbol{C R}(\mathbf{m d d})$ & $\boldsymbol{I E}(\boldsymbol{\%})$ & $\boldsymbol{C R}(\mathbf{m d d})$ & $\boldsymbol{I E}(\boldsymbol{\%})$ \\
\hline 0 & 58.18 & - & 51.19 & 12 \\
2 & 50.03 & 14 & 30.83 & 47 \\
4 & 44.80 & 23 & 25.02 & 57 \\
6 & 39.56 & 32 & 19.78 & 66 \\
8 & 33.16 & 43 & 13.38 & 77 \\
10 & 27.34 & 53 & 7.56 & 87 \\
\hline
\end{tabular}

It is observed from Table 2 that Allium sativum is a good inhibitor. The $I E$ is found to be enhanced in the presence of $\mathrm{Zn}^{2+}$ ion. The active principle of Allium sativum extract has coordinated with $\mathrm{Fe}^{2+}$ on the metal surface and forms a protective film consisting of $\mathrm{Fe}^{2+}-$ Allicin complex. The formulation consisting of $10 \mathrm{~mL}$ of Allium sativum and $50 \mathrm{ppm}$ of $\mathrm{Zn}^{2+}$ shows $87 \%$ of inhibition efficiency. Weight loss study reveals that Allium sativum and $\mathrm{Zn}^{2+}$ individually showed some $I E$, but exhibited better $I E$, when applied in combination.

\section{Analysis of potentiodynamic polarization curves}

Polarization study is useful in confirming the formation of protective film formed on the metal surface [21, 22]. The polarization resistance is inversely proportional to the rate of corrosion expressed as the equivalent corrosion current density $I_{\text {corr. }}$. If a protective film is formed, the linear polarization resistance increases and the corrosion current value will decrease. The polarization curves of mild steel immersed in $100 \mathrm{~mL}$ of the SOWW containing various concentrations of the inhibitor (Allium sativum) in the absence and presence of $\mathrm{Zn}^{2+}$ are shown in Figure 1.

The corrosion parameters such as corrosion potential $\left(E_{\text {corr }}\right)$, corrosion current $\left(I_{\text {corr }}\right)$, linear polarization resistance (LPR) and Tafel slopes $\left(b_{\mathrm{c}}=\right.$ cathodic; $b_{\mathrm{a}}=$ anodic) are given in Table 3.

It is observed from the Table 3 that when mild steel is immersed in simulated oil well water, the corrosion potential is $-777 \mathrm{mV}$ vs. SCE. The corrosion current is $1.034 \cdot 10^{-4}$ $\mathrm{A} / \mathrm{cm}^{2}$. The $\mathrm{LPR}$ value is $482 \mathrm{Ohm} \cdot \mathrm{cm}^{2}$. When Allium sativum $(10 \mathrm{~mL})$ and $\mathrm{Zn}^{2+}(50 \mathrm{ppm})$ are added to the above system the corrosion potential is shifted to the cathodic side $-880 \mathrm{mV}$ 
vs. SCE. The LPR value increases from 482 to $1831 \mathrm{Ohm} \cdot \mathrm{cm}^{2}$. The corrosion current decreases from $1.034 \cdot 10^{-4}$ to $0.1515 \cdot 10^{-4} \mathrm{~A} / \mathrm{cm}^{2}$. These observations confirm that a protective film is formed on the metal surface. This controls the corrosion of metal.

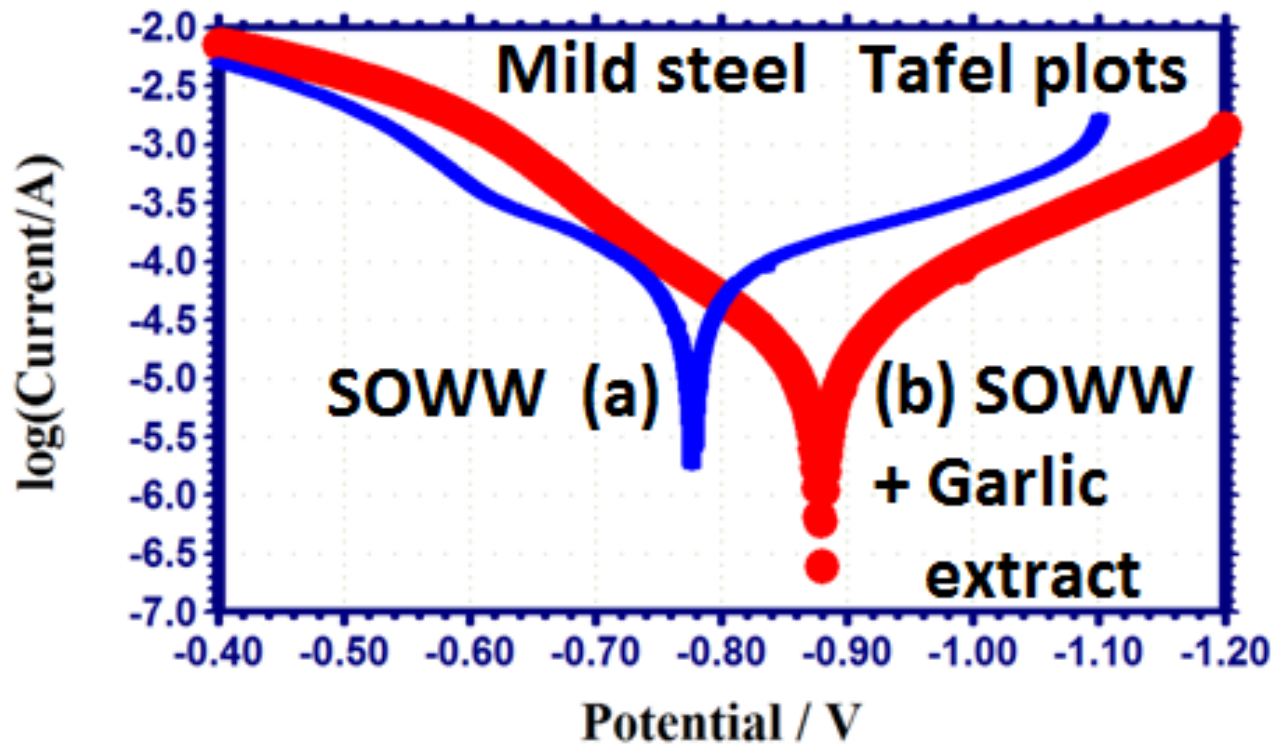

Figure 1. Polarization curves of mild steel immersed in various test solution: a) SOWW; $b$ ) Allium sativum extract $10 \mathrm{~mL}+\mathrm{Zn}^{2+} 50 \mathrm{ppm}$.

Table 3. Corrosion parameters of mild steel immersed in SOWW in the absence and presence of Allium sativum extract and $50 \mathrm{ppm}$ of $\mathrm{Zn}^{2+}$ obtained by Polarization study.

\begin{tabular}{cccccc}
\hline System & $\begin{array}{c}\mathbf{E}_{\mathbf{c o r r}} \\
\mathbf{m V} \boldsymbol{v s .} \mathbf{S C E}\end{array}$ & $\begin{array}{c}\boldsymbol{b}_{\mathbf{c}} \\
\mathbf{m V} / \mathbf{d e c a d e}\end{array}$ & $\begin{array}{c}\boldsymbol{b}_{\mathbf{a}} \\
\mathbf{m V} / \mathbf{d e c a d e}\end{array}$ & $\begin{array}{c}\mathbf{L P R} \\
\mathbf{O h m} \cdot \mathbf{c m}^{2}\end{array}$ & $\begin{array}{c}\boldsymbol{I}_{\text {corr }} \\
\mathbf{A} / \mathbf{c m}^{2}\end{array}$ \\
\hline $\begin{array}{c}\text { SOWW } \\
\text { SOWW + Allium }\end{array}$ & -777 & 265 & 202 & 482 & $1.034 \cdot 10^{-4}$ \\
sativum extract & -880 & 119 & 138 & 1831 & $0.1515 \cdot 10^{-4}$ \\
\hline
\end{tabular}

Analysis of AC Impedance spectra

AC impedance spectra (electrochemical impedance spectra) have been used to confirm the formation of protective film on the metal surface. If a protective film is formed on the metal surface, charge transfer resistance increases $\left(R_{\mathrm{t}}\right)$, double layer capacitance value $\left(C_{\mathrm{dl}}\right)$ decreases and the impedance $\log (\mathrm{Z} / \mathrm{Ohm})$ value increases [23]. The AC impedance spectra of mild steel immersed in simulated oil well water in the absence and presence of inhibitors (Allium sativum- $\mathrm{Zn}^{2+}$ ) are shown in Figure 2 (Nyquist plots). It is observed from that when mild steel immersed in aqueous SOWW two semi circles were observed. This is characteristic of a protective film formed and then broken. The breaking of the film is due to the presence of corrosive ions present in solution. The equivalent circuit diagram for such system is shown in Figure 3. 


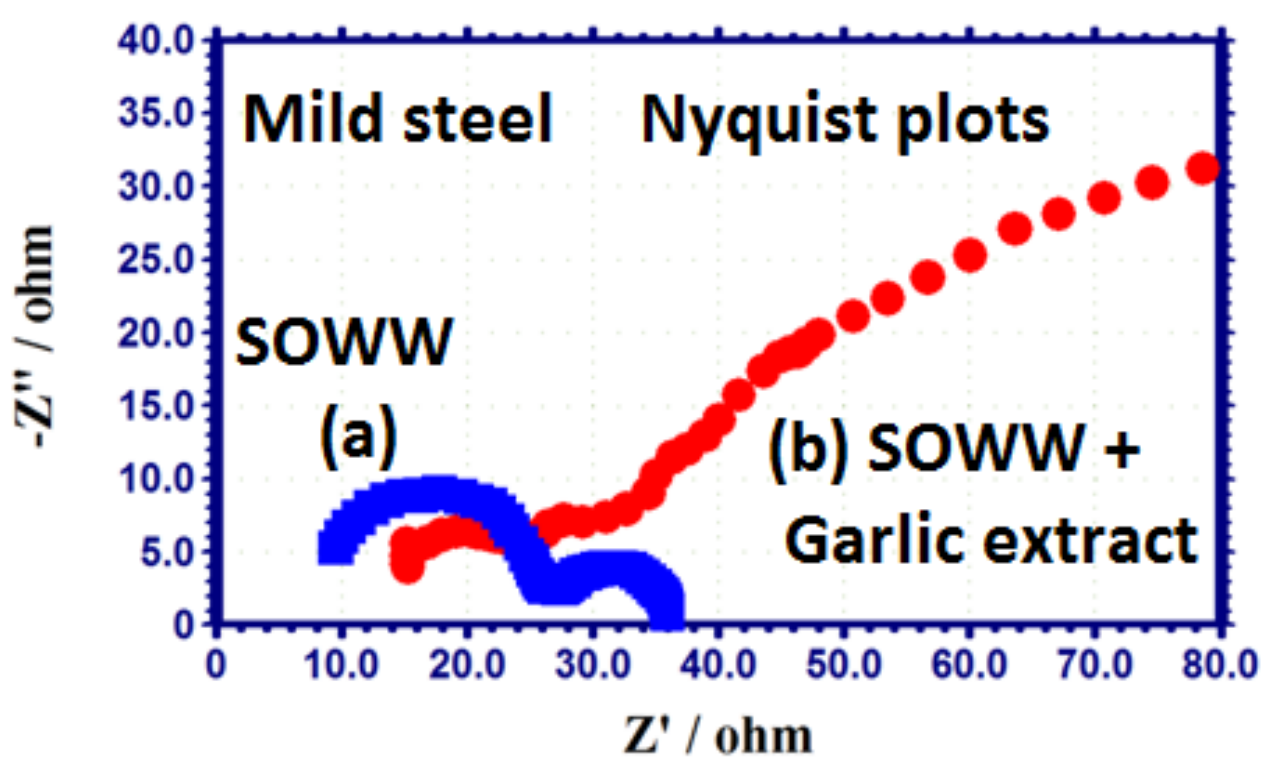

Figure 2. AC Impendence curves of mild steel immersed in various test solution (Nyquist plots): a) SOWW; b) SOWW + Allium sativum extract $10 \mathrm{~mL}+\mathrm{Zn}^{2+} 50 \mathrm{ppm}$.

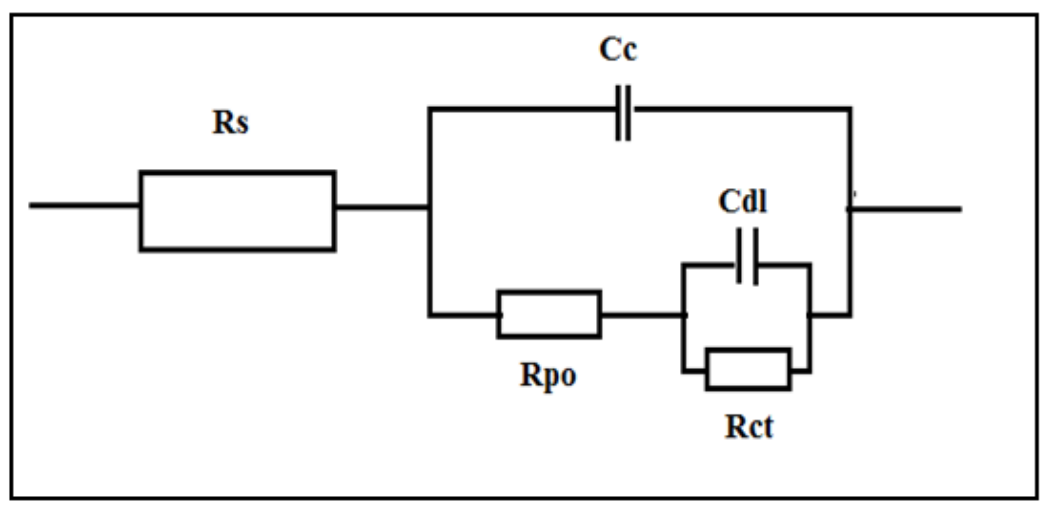

Figure 3. Equivalent circuit for a failed coating. $C_{\mathrm{c}}-$ the capacitance of the intact coating, $R_{\mathrm{po}}$ - pore resistance, $R_{\mathrm{ct}}$ - charge transfer resistance, $R_{\mathrm{s}}$ - solution resistance, $C_{\mathrm{dl}}$ - double layer capacitance.

The AC impedance spectra of mild steel immersed in simulated oil well water in the absence and presence of inhibitors (Allium sativum- $\mathrm{Zn}^{2+}$ ) are shown in Figure 4 and Figure 5 (Bode plots).

The AC impedance parameters namely charge transfer resistance $\left(R_{\mathrm{t}}\right)$ and double layer capacitance $\left(C_{\mathrm{dl}}\right)$ and the impedance $\log (Z / \mathrm{Ohm})$ values are calculated from Bode plots [24] and are given in Table 4. 

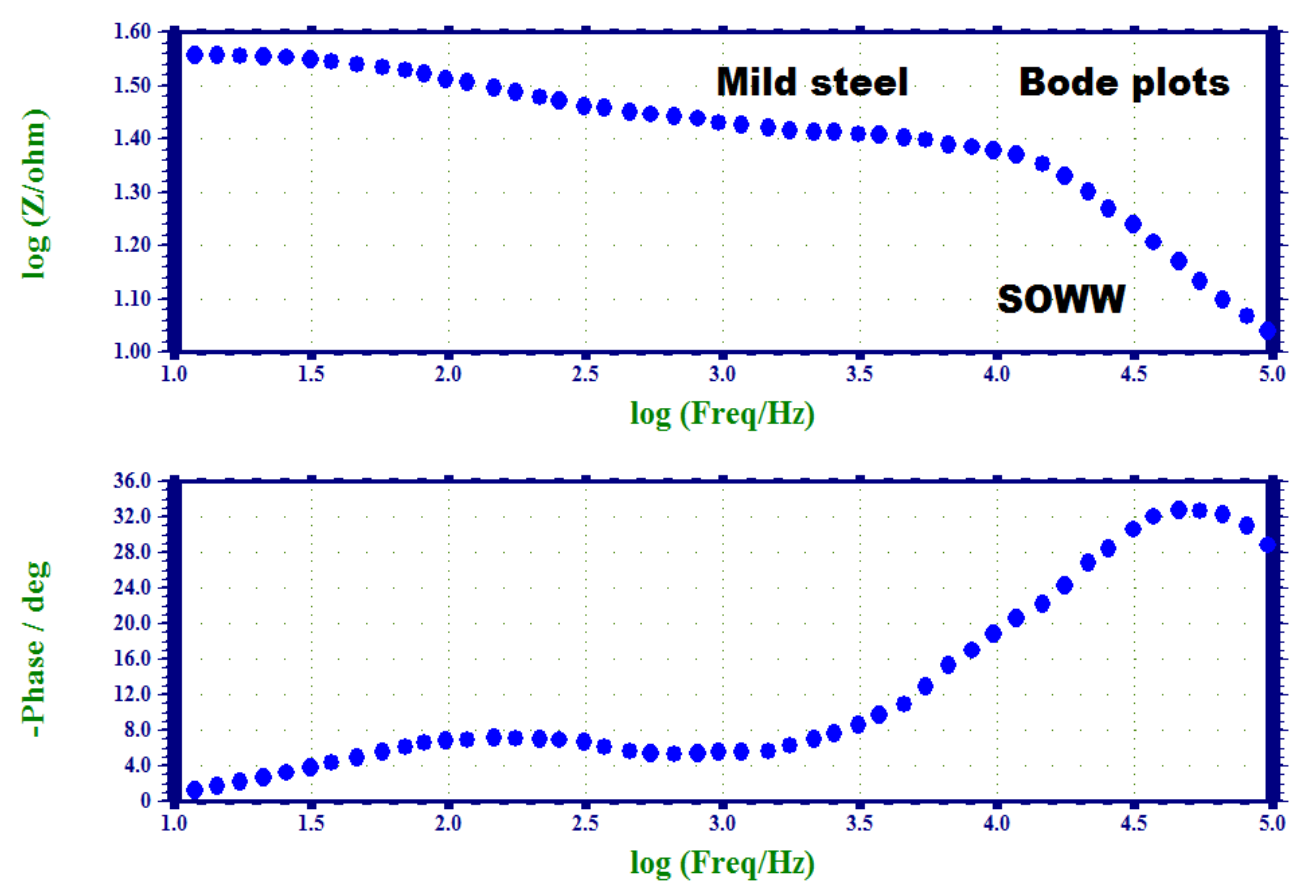

Figure 4. AC impendence spectra of mild steel immersed in SOWW (Bode plots).
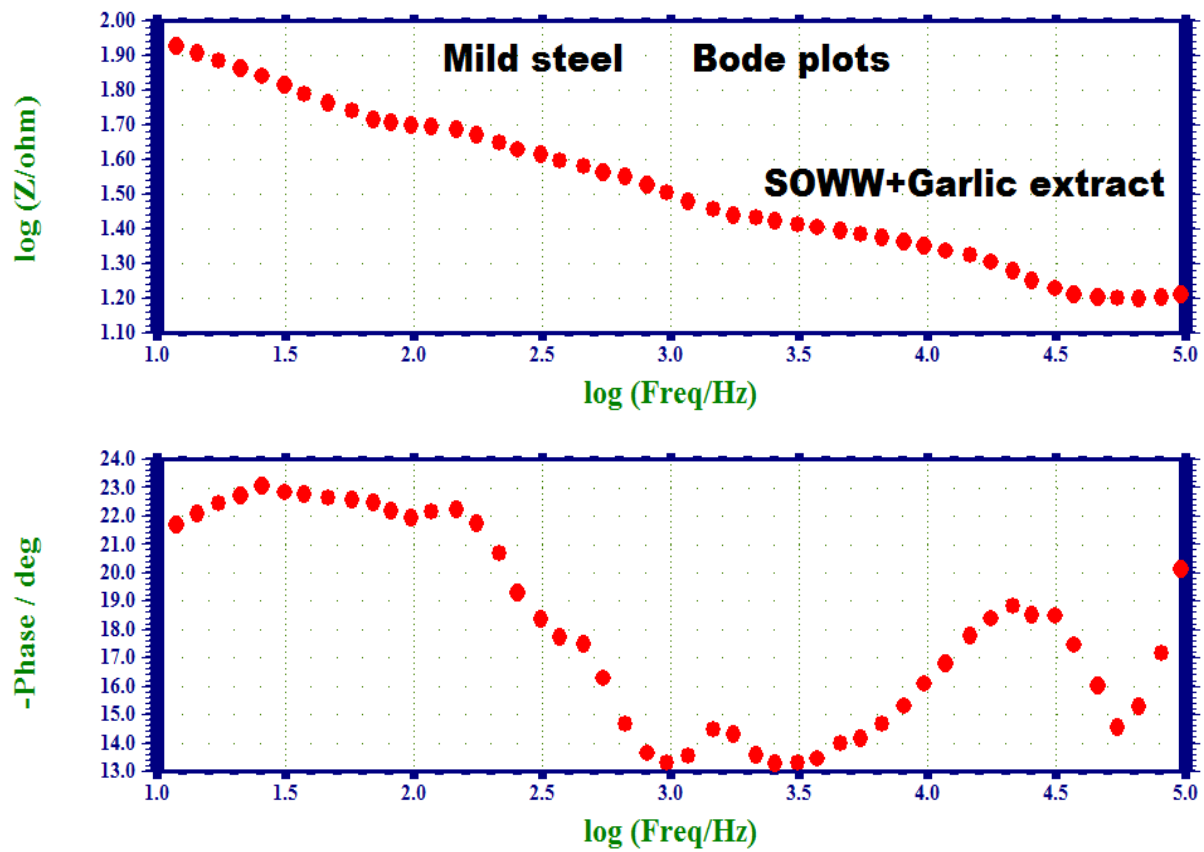

Figure 5. AC impendence spectrum of mild steel immersed in SOWW + $10 \mathrm{~mL}$ Allium sativum $+50 \mathrm{ppm}$ of $\mathrm{Zn}^{2+}$ system (Bode plots).

It is observed that when the inhibitors Allium sativum $(10 \mathrm{~mL})+\mathrm{Zn}^{2+}(50 \mathrm{ppm})$ are added to SOWW, the charge transfer resistance $\left(R_{\mathrm{t}}\right)$ increases from $22.871 \mathrm{Ohm} \cdot \mathrm{cm}^{2}$ to $66.32 \mathrm{Ohm} \cdot \mathrm{cm}^{2}$. The $C_{\mathrm{dl}}$ value decreases from $1.82 \cdot 10^{-7} \mathrm{~F} / \mathrm{cm}^{2}$ to $7.68 \cdot 10^{-8} \mathrm{~F} / \mathrm{cm}^{2}$. The impedance value $[\log (Z / O h m)]$ increases from 1.577 to 1.956 . These results lead to the 
conclusion that a protective film is formed on the metal surface [25] in the presence of inhibitors [Allium sativum- $\mathrm{Zn}^{2+}$. Equivalent circuit diagram for such a system is shown in Figure 6 . The circuit models a cell where polarization is due to a combination of kinetic and diffusion process.

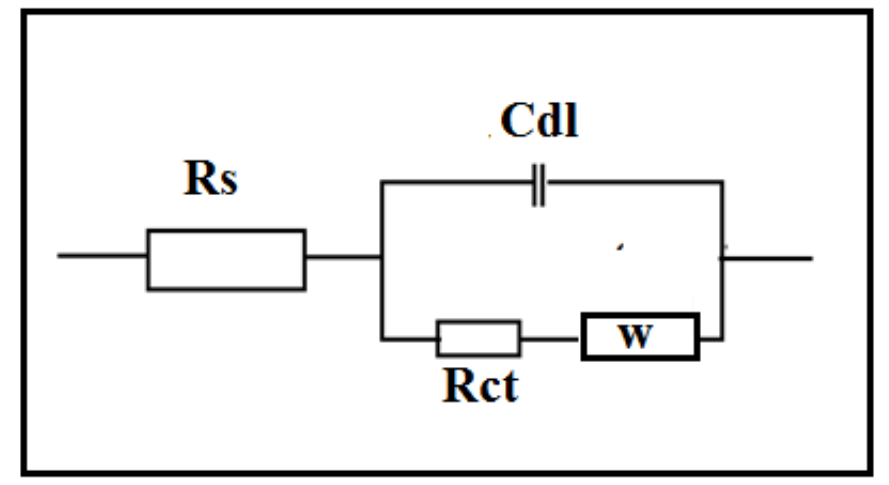

Figure 6. $R_{\mathrm{S}}$ - solution resistance, $R_{\mathrm{ct}}$ - charge transfer resistance, $W$ - Warburg diffusion resistance, $C_{\mathrm{dl}}-$ Double layer capacitance.

\section{Analysis of FTIR Spectra}

The active principle in an aqueous extract of Allium sativum is allicin. It consists of $\mathrm{S}=\mathrm{O}$ and $\mathrm{S}$ groups. A few drops of an aqueous extract of garlic were dried on a glass plate. A solid mass was obtained. Its FTIR spectrum is shown Figure 7.

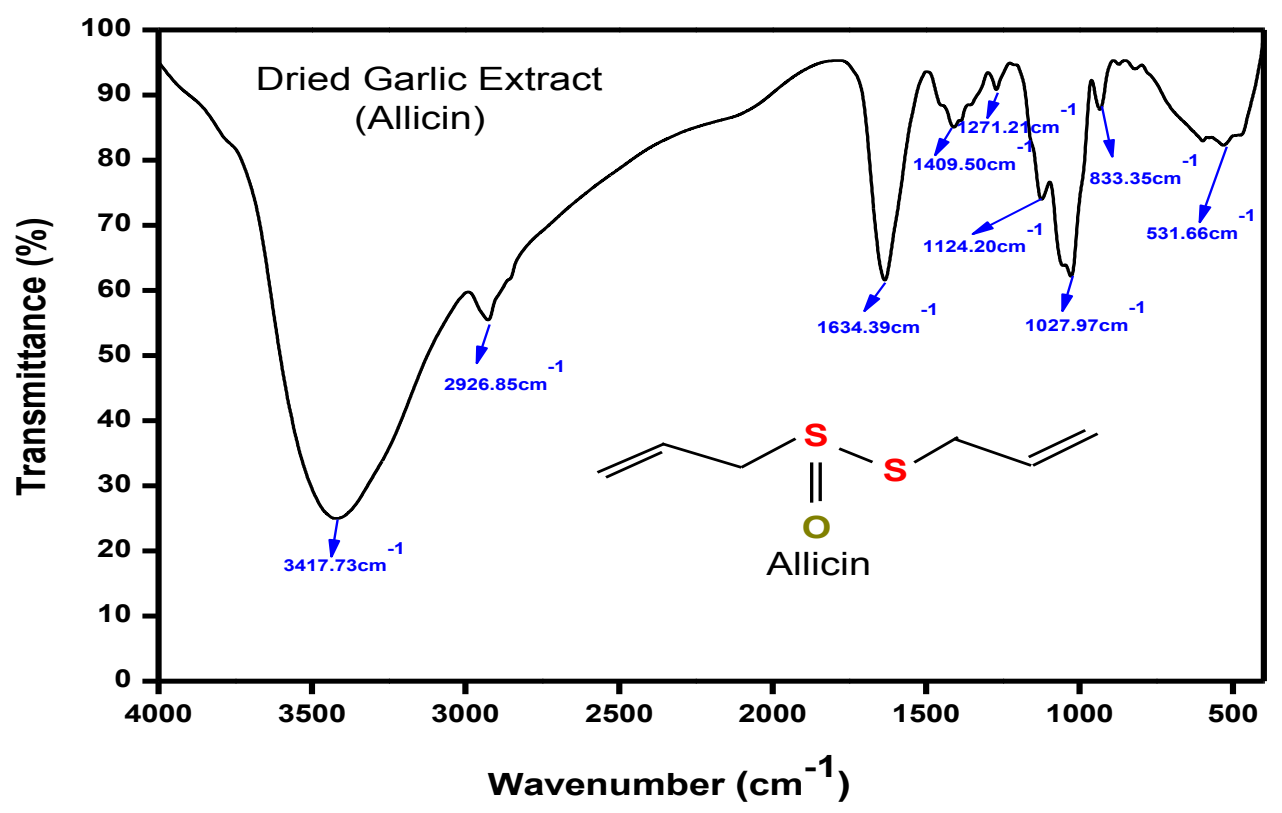

Figure 7. FTIR spectrum of pure Allium sativum. 


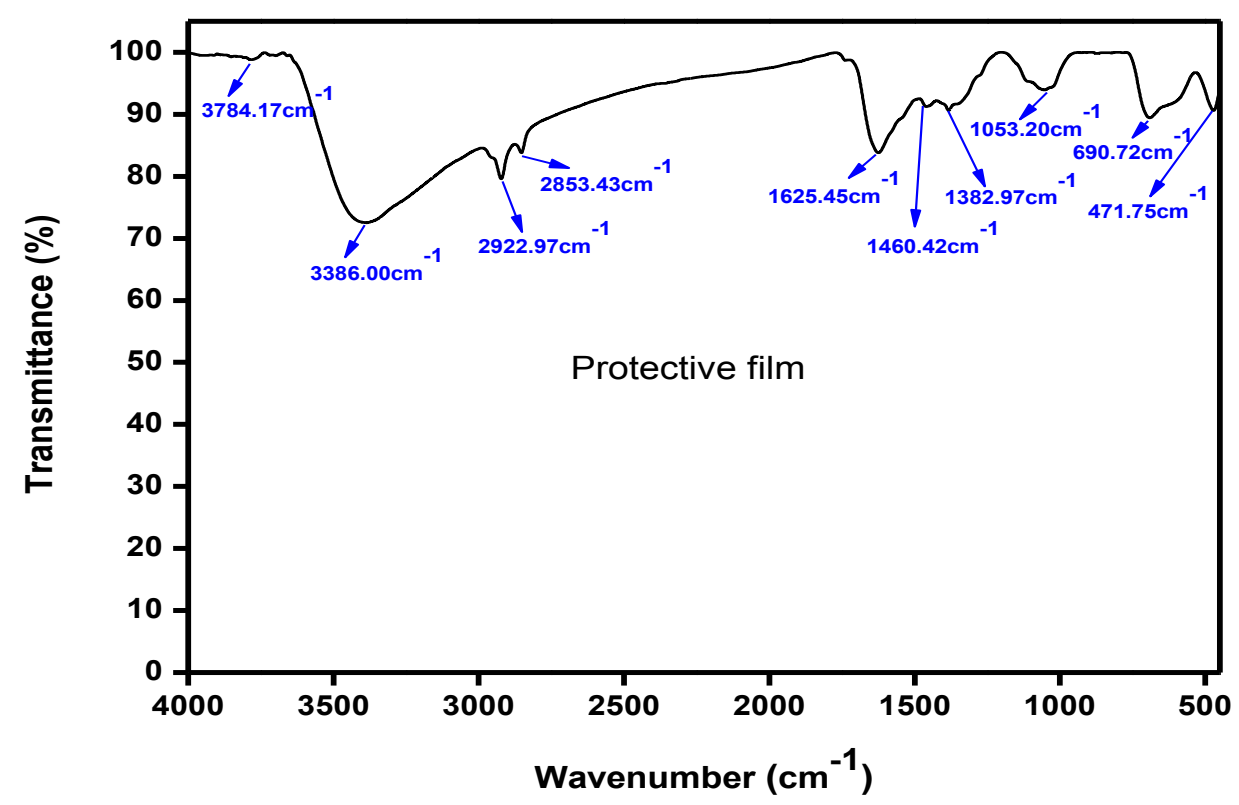

Figure 8. FTIR spectrum of inhibitor film formed on the mild steel after immersion in SOWW containing $10 \mathrm{~mL}$ of Allium sativum and $50 \mathrm{ppm}$ of $\mathrm{Zn}^{2+}$.

Vinyl group appeared at $1053.20 \mathrm{~cm}^{-1} . \mathrm{S}=\mathrm{O}$ appeared at $1053 \mathrm{~cm}^{-1}$ and $\mathrm{S}$ at $471.75 \mathrm{~cm}^{-1}$. Thus, the structure of allicin is confirmed by FTIR spectra [26]. The FTIR spectrum of the protective film formed on the surface of the metal after immersion in the SOWW containing inhibitor Allium sativum extract and $\mathrm{Zn}^{2+}$ is shown in Figure 8.

The band at $690.72 \mathrm{~cm}^{-1}$ corresponds to $\mathrm{Zn}-\mathrm{O}$ stretching. The $\mathrm{OH}$ stretching frequency appears at $3386.00 \mathrm{~cm}^{-1}$. This confirms the formation of $\mathrm{Zn}(\mathrm{OH})_{2}$ on the cathodic sites of the metal surface [27]. Since there is complete coordination between $\mathrm{Fe}^{2+}$ and allicin, the band due to the formation of the complex gets vanished in the FTIR spectrum of the film formed on the surface of mild steel by Allium sativum extract (Figure 8) [28].

\section{Surface Analysis}

Surface morphology of mild steel was studied by scanning electron microscopy after 24 hours immersion in simulated oil well water before and after addition of inhibitor. Figure 9(a) represent the micrograph obtained of polished steel without being exposed to the corrosive environment while Figure 9(b) showed strongly damaged steel surface due to the formation of corrosion products after immersion in SOWW. SEM images of steel surface

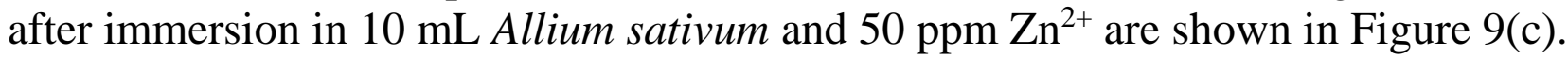

The SEM micrograph of Figure 9(a) shows the smooth surface of mild steel without any corrosion product or inhibitor complex on the metal surface. Inspection of Figure 9(b) reveals that the mild steel immersed in SOWW shows an aggressive attack of the corroding medium

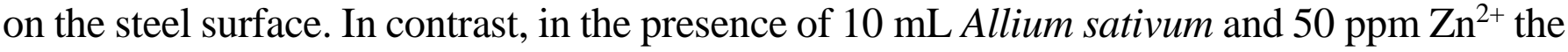
mild steel surface coverage increases which in turn results in the formation of insoluble complex on the metal surface (Allium sativum $+\mathrm{Zn}^{2+}$ inhibitor complex) Figure 9(c) [29]. 


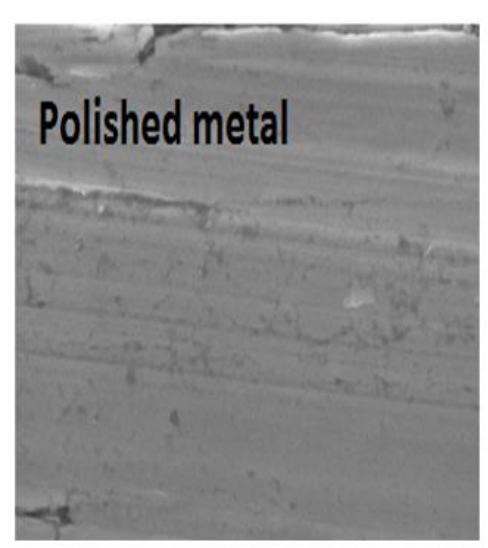

$\mathbf{a}$

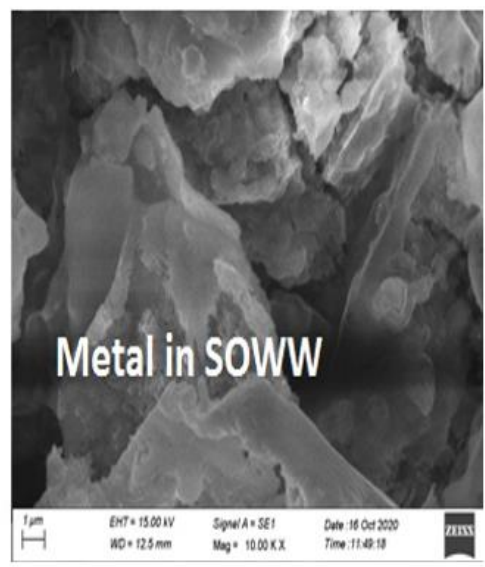

b

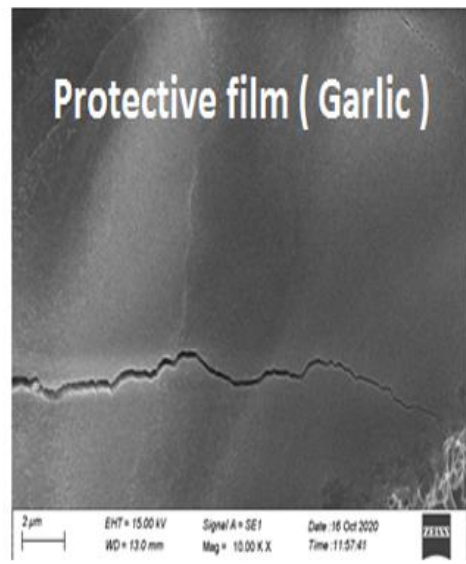

c

Figure 9. SEM micrographs of (a) mild steel; (b) mild steel immersed in SOWW; (c) mild steel immersed in SOWW containing $10 \mathrm{~mL}$ Allium sativum and $50 \mathrm{ppm} \mathrm{Zn}^{2+}$.

\section{Atomic Force Microscopy Characterization}

Atomic Force Microscopy (AFM Analysis) provides images with atomic or near-atomicresolution surface topography, capable of quantifying surface roughness of samples down to the angstrom-scale. Atomic force microscopy (AFM) or scanning force microscopy (SFM) is a very higher resolution type of scanning probe microscopy, with demonstrated resolution on the order of fractions of a nanometer, more than 1000 times better than the optical diffraction limit. The three-dimensional (3D) AFM morphologies and the AFM crosssectional profile for polished mild steel surface (reference sample), mild steel surface immersed in SOWW (blank sample) and mild steel surface immersed in SOWW containing the formulation of $10 \mathrm{~mL}$ garlic extract and $50 \mathrm{ppm}$ of $\mathrm{Zn}^{2+}$ are shown as Figure 10, Figure 11 and Figure 12 respectively [30].

Table 5. AFM data for mild steel surface immersed in inhibited and uninhibited environment.

\begin{tabular}{cccc}
\hline Samples & $\begin{array}{c}\text { Average Roughness } \\
\left(\boldsymbol{R}_{\mathbf{a}}\right)(\mathbf{n m})\end{array}$ & $\begin{array}{c}\text { RMS Roughness }\left(\boldsymbol{R}_{\mathbf{q}}\right) \\
(\mathbf{n m})\end{array}$ & $\begin{array}{c}\text { Maximum peak }- \\
\text { valley height }\left(\boldsymbol{R}_{\mathbf{y}}\right)(\mathbf{n m})\end{array}$ \\
\hline Polished & 4.8228 & 6.3498 & 37.465 \\
SOWW & 288.73 & 382.33 & 1849.3 \\
SOWW+Allium & 45.381 & 51.214 & 179.62 \\
sativum $+\mathrm{Zn}^{2+}$ & & & \\
\hline
\end{tabular}

Figure 10 displays the surface topography of un-corroded metal surface. The value of $R_{\mathrm{a}}, R_{\mathrm{q}}$ and $R_{\mathrm{y}}$ for the polished mild steel surface (reference sample) are $4.8228 \mathrm{~nm}$, $6.3498 \mathrm{~nm}$ and $37.465 \mathrm{~nm}$ respectively. The slight roughness observed on the polished mild 
steel surface is due to atmospheric corrosion. Figure 11 displays the corroded metal surface with few pits in the absence of the inhibitor immersed in SOWW. The $R_{\mathrm{a}}, R_{\mathrm{q}}, R_{\mathrm{y}}$ values for the mild steel surface is $288.73 \mathrm{~nm}, 382.33 \mathrm{~nm}$ and $1849.3 \mathrm{~nm}$ respectively. These data suggests that mild steel surface immersed in SOWW has a greater surface roughness than the polished metal surface, which shows that the unprotected mild steel surface is rougher and was due to the corrosion of the mild steel in SOWW environment. Figure 12 displays the steel surface after immersion in SOWW containing $10 \mathrm{~mL}$ of Allium sativum and $50 \mathrm{ppm}$ of $\mathrm{Zn}^{2+}$. The $R_{\mathrm{a}}, R_{\mathrm{q}}, R_{\mathrm{y}}$ values for the mild steel surface are $45.381 \mathrm{~nm}, 51.214 \mathrm{~nm}$ and $179.62 \mathrm{~nm}$ respectively. The $R_{\mathrm{a}}, R_{\mathrm{q}}, R_{\mathrm{y}}$ values are considerably less in the inhibited environment compared to the uninhibited environment. These parameters confirm that the surface is smoother. The smoothness of the surface is due to the formation of a compact protective film of $\mathrm{Fe}^{2+}-$ Allicin complex and $\mathrm{Zn}(\mathrm{OH})_{2}$ on the metal surface there by inhibiting the corrosion of mild steel [29].

AFM image analysis was performed to obtain the average roughness, $R_{\mathrm{a}}$ (the average deviation of all points roughness profile from a mean line over the evaluation length), rootmean-square roughness, $R_{\mathrm{q}}$ (the average of the measured height deviations taken within the evaluation length and measured from the mean line) and the maximum peak-to-valley $R_{\mathrm{y}}$ height values (largest single peak-to-valley height in five adjoining sampling heights). Table 5 is a summary of $\left(R_{\mathrm{q}}\right),\left(R_{\mathrm{a}}\right),\left(R_{\mathrm{y}}\right)$ values for mild steel surface immersed in different environments.

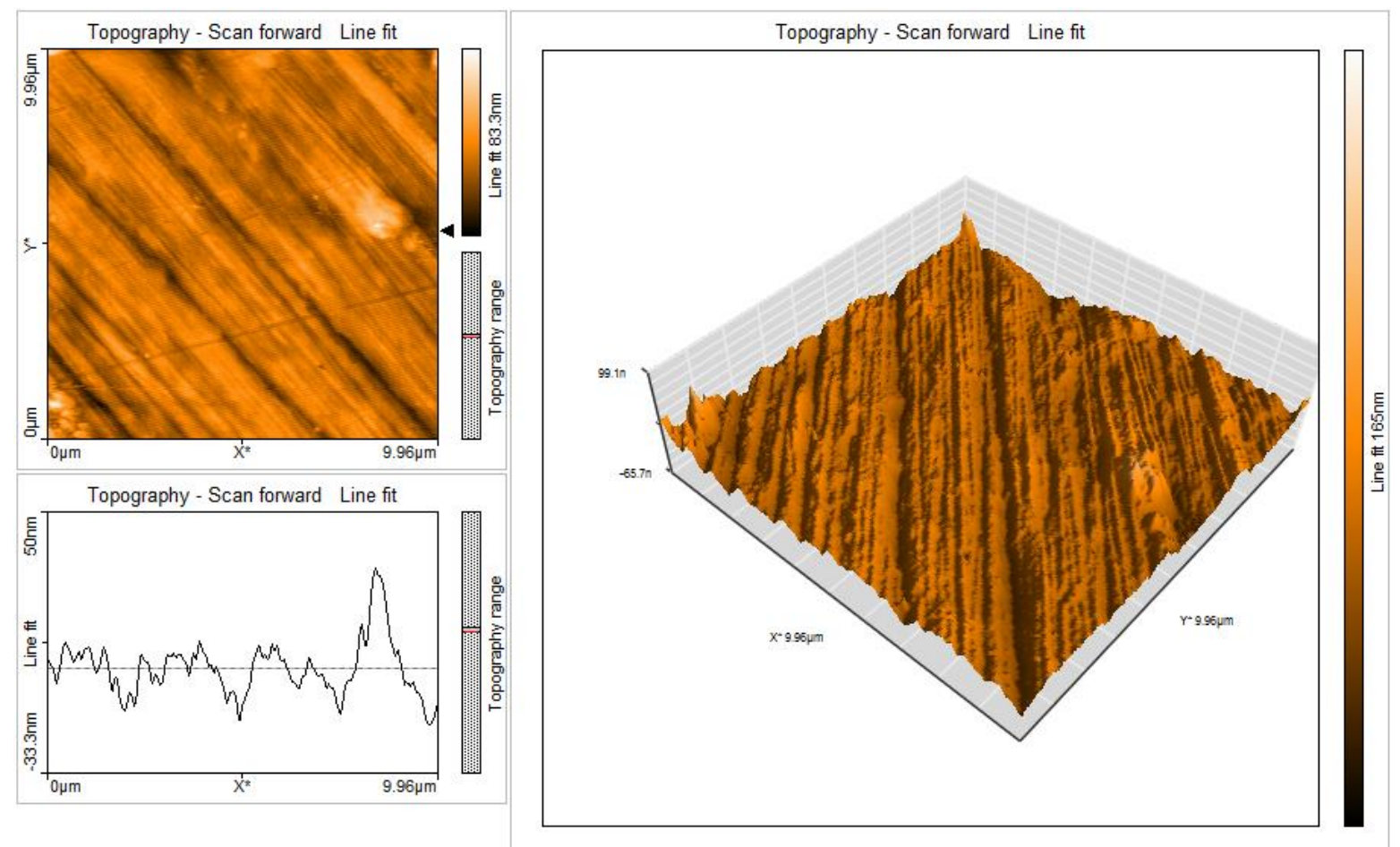

Figure 10. Three dimensional and cross-sectional AFM images of the surface of polished mild steel (control). 


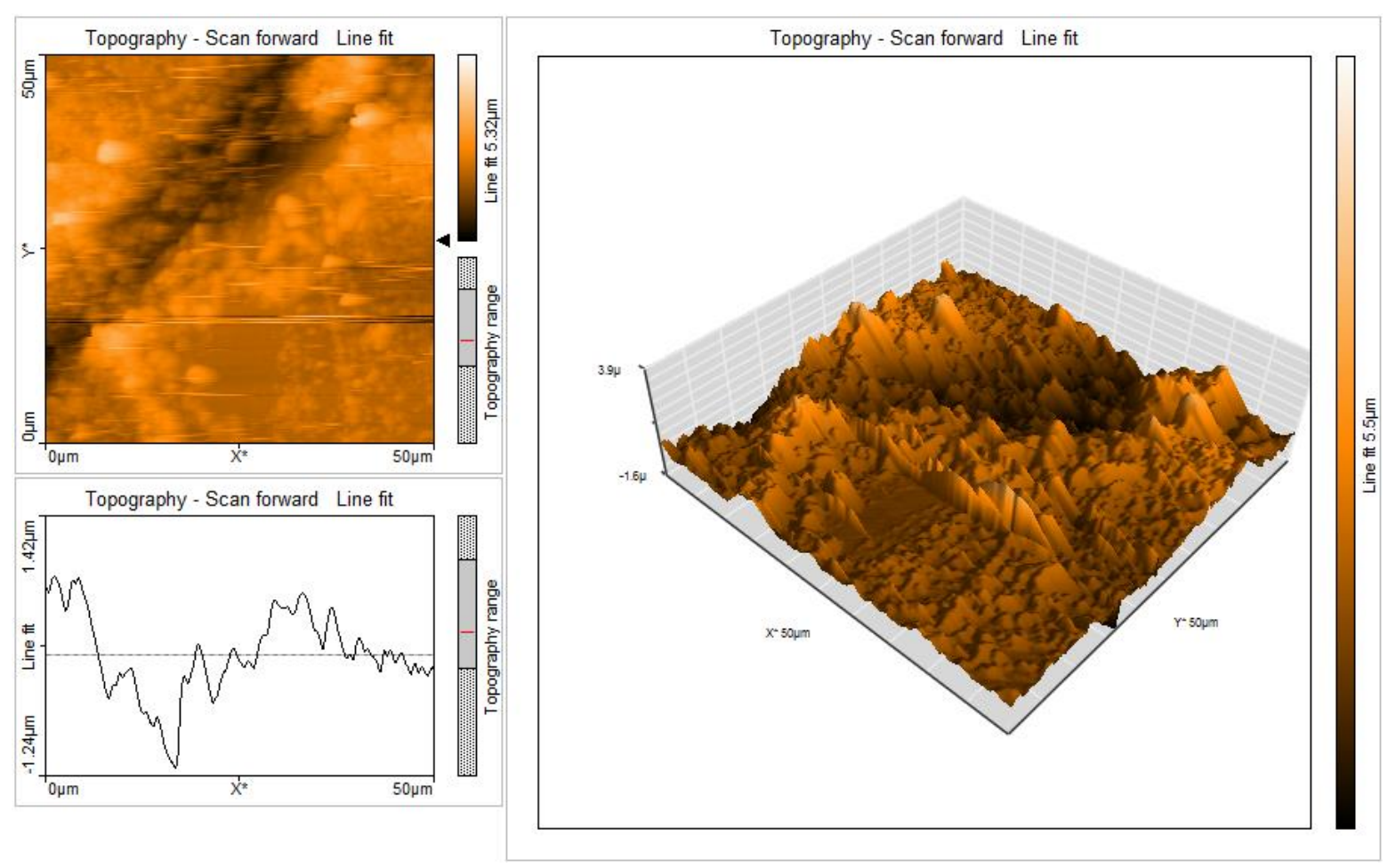

Figure 11. Three dimensional and cross-sectional AFM images of the surface of mild steel immersed in SOWW (blank).

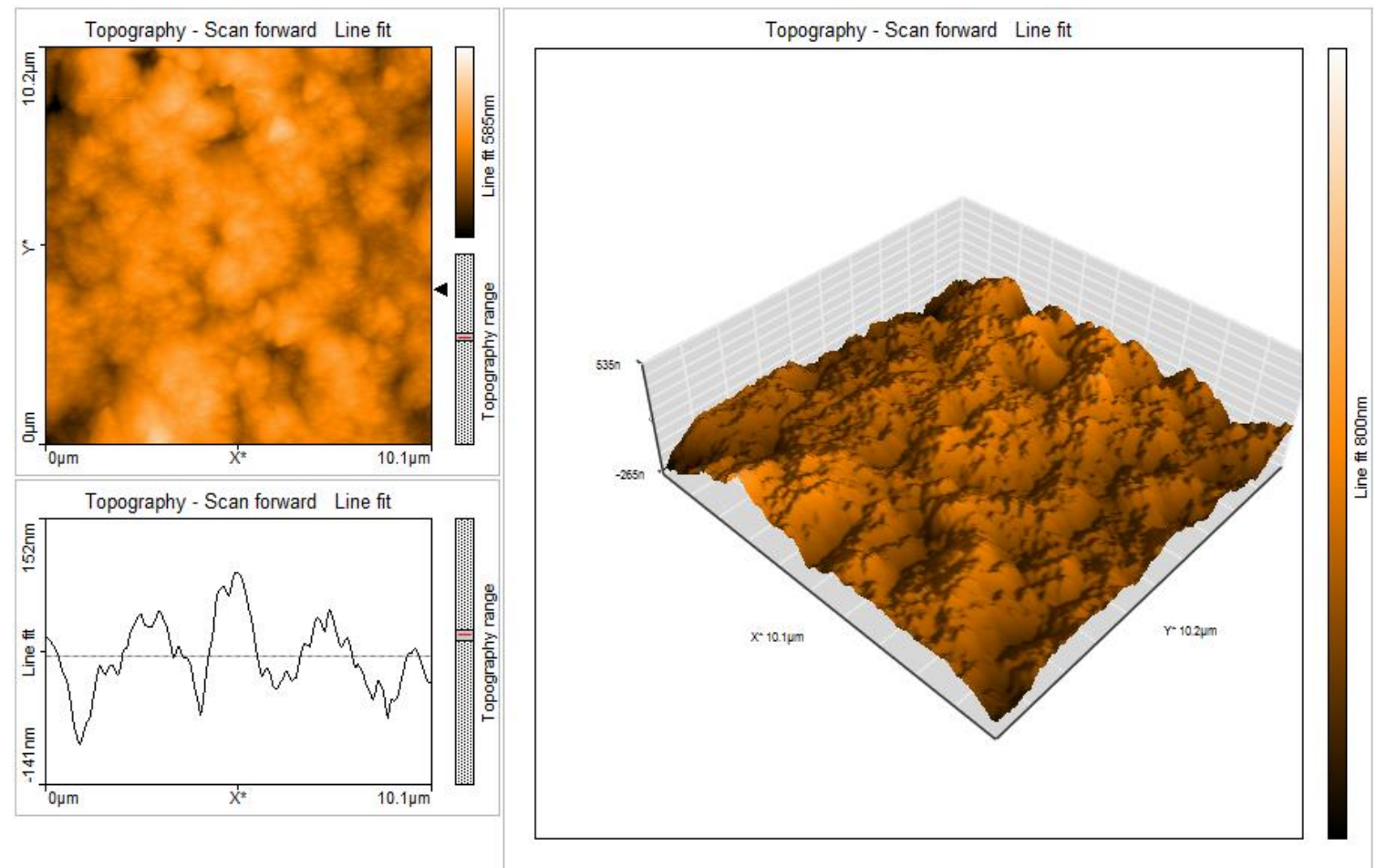

Figure 12. Three dimensional and cross-sectional AFM images of the surface of mild steel immersed in SOWW containing $10 \mathrm{~mL}$ Allium sativum and $50 \mathrm{ppm} \mathrm{Zn}^{2+}$. 


\section{Conclusion}

The present study leads to the following conclusions:

i. The formulation consisting of $10 \mathrm{~mL}$ of Allium sativum and $50 \mathrm{ppm}$ of $\mathrm{Zn}^{2+}$ offers $87 \%$ IE to mild steel immersed in $100 \mathrm{~mL}$ of simulated oil well water.

ii. Polarization study reveals that Allium sativum system controls the cathodic reaction predominantly.

iii. AC impedance spectra reveal that a protective film is formed on the metal surface.

iv. FTIR spectra reveal that the inhibitive film consists of $\mathrm{Fe}^{2+}-$ Allium sativum complex.

v. SEM and AFM images confirmed the protective film formed on the metal surface was smooth and stable.

\section{References}

1. Y.M. Panchenko and A.I. Marshakov, Long-term prediction of metal corrosion losses in atmosphere using a power-linear function, Corros. Sci., 2016, 109, 217-229. doi: 10.1016/j.corsci.2016.04.002

2. N.S. Hassan, Eng. Technol. J., 2013, 31A, 1182-1193.

3. A.Y. Badmos, H.A. Ajimotokan and E.O. Emmanuel, New York Sci. J., 2009, 2, no. 5, $36-40$.

4. L. Herrag, B. Hammouti, S. Elkadiri, A. Aouniti, C. Jama, H. Vezin and F. Bentiss, Adsorption properties and inhibition of mild steel corrosion in hydrochloric solution by some newly synthesized diamine derivatives: Experimental and theoretical investigations, Corros. Sci., 2010, 52, no. 9, 3042-3051. doi: 10.1016/j.corsci.2010.05.024

5. P.C. Okafor, M.E. Ikpi, I.E. Uwah, E.E. Ebenso, U.J. Ekpe and S.A. Umoren, Inhibitory action of Phyllanthus amarus extracts on the corrosion of mild steel in acidic media, Corros. Sci., 2008, 50, no. 8, 2310-2317. doi: 10.1016/j.corsci.2008.05.009

6. S. Jyothi, Y.V.S. Rao and P.S.S. Ratnakumar, Effect of nickel dopant on structural, morphological and optical characteristics of $\mathrm{Fe}_{3} \mathrm{O}_{4}$ nanoparticles, Rasayan J. Chem., 2019, 12, no. 2, 537-544. doi: 10.31788/RJC.2019.1225054

7. S. Rajendran, R. Srinivasan, R. Dorothy, T. Umasankareswari and A.A. Hashem, Corrosion inhibition of mild steel in seawater through green approach using Leucaena leucocephala leaves extract, Int. J. Corros. Scale Inhib., 2019, 8, no. 3, 473-479. doi: 10.17675/2305-6894-2019-8-3-12

8. P. Mahalakshmi, S. Rajendran, G. Nandhini, S.C. Joycee, N. Vijaya, T. Umasankareswari and N. Renuga Devi, Inhibition of corrosion of mild steel in sea water by an aqueous extract of turmeric powder, Int. J. Corros. Scale Inhib., 2020, 9, no. 2, 706-725. doi: $10.17675 / 2305-6894-2020-9-2-20$

9. T. Sathyyariya, G. Rathika and K. Kanagavalli, Int. J. Sci. Eng. Res., 2014, 5, 14111416. 
10. K. Anbarasi and V.G. Vasudha, Corrosion inhibition potential of Cucurbita maxima plant extract on mild steel in acid media, Chem. Sci. Rev. Lett., 2014, 3, CS2320440212, $45-51$.

11. L.D. Lawson and R. Bauer, Phytomedicines of Europe. Chemistry and Biological Activity, J. Med. Chem., 1999, 42, 9, 176-209. doi: 10.1021/jm990008n

12. R.S. Rivlin, Historical Perspective on the Use of Garlic, J. Nutr., 2001, 131, 951S-954S. doi: $10.1093 / \mathrm{jn} / 131.3 .951 \mathrm{~S}$

13. K. Rajam, S. Rajendran and R. Saranya, Allium Sativum (Garlic) Extract as Nontoxic Corrosion Inhibitor, J. Chem., 2013, 743807. doi: 10.1155/2013/743807

14. M. Sangeetha, S. Rajendran, T.S. Muthu Megala and K. Krishnaveni, Zast. Mater., 2011, 52, 35-39.

15. M. Vakili Azghandi, A. Davoodi, G.A. Farzi and A. Kosari, Water-base acrylic terpolymer as a corrosion inhibitor for SAE1018 in simulated sour petroleum solution in stagnant and hydrodynamic conditions, Corros. Sci., 2012, 64, 44-54. doi: 10.1016/j.corsci.2012.07.003

16. K. Kavitha, H. Benita sherine and S. Rajendran, Anti-corrosive properties of an aqueous extract of Chrysanthemum indicum flower, Int. J. Corros. Scale Inhib., 2021, 10, no. 2, 783-800. doi: 10.17675/2305-6894-2021-10-2-19

17. P. Shanthy, J.A. Thangakani, S. Karthika, S.C. Joycee, S. Rajendran and J. Jeyasundari, Corrosion inhibition by an aqueous extract of Ervatamia divaricate, Int. J. Corros. Scale Inhib., 2021, 10, no. 1, 331-348. doi: 10.17675/2305-6894-2021-10-1-19

18. N. Karthiga, S. Rajendran, P. Prabhakar, A. Al-Hashem and S. Shanmugapriya, Corrosion inhibition of mild steel by an aqueous extract of allium sativum, Eur. $J$. Biomed. Pharm. Sci., 2018, 5, no. 2, 838-843.

19. G. Geetha, J.C. Angelin, S. Krishnaveni, N. Karthiga, J.M. Praveena, S. Rajendran and J.A. Thangakani, Corrosion resistance of orthodontic wires made of thermo active alloy and SS 18/8 alloy in a beverage (hard drink) decreases on dilution with water, Int. J. Corros. Scale Inhib., 2021, 10, no. 1, 388-398. doi: 10.17675/2305-6894-2020-10-1-22

20. A. Grace Baby, S. Rajendran, V. Johnsirani, A. Hashem, N. Karthiga and P. Nivetha, nfluence of zinc sulphate on the corrosion resistance of L80 alloy immersed in sea water in the absence and presence of sodium potassium tartrate and trisodium citrate, Int. J. Corros. Scale Inhib., 2020, 9, no. 3, 979-999. doi: 10.17675/2305-6894-2020-9-3-12

21. J. Angelin Thangakani, S. Rajendran, J. Sathiyabama, RM. Joany, R.J. Rathish and S.S. Prabha, Int. J. Nano. Corr. Sci. Eng., 2014, 1, no. 1, 50-62.

22. A.C.C. Mary, S. Rajendran, H. Al Hashem, R.J. Rathish, T. Uma Sankareswari and J. Jeyasundari, Int. J. Nano Corr. Sci. Eng., 2015, 2, no. 1, 42-50.

23. V. Johnsirani, S. Rajendran, A.C.C. Mary, R.J. Rathish, T. Uma Sankareswari and J. Jeyasundari, Int. J. Nano Corr. Sci. Eng., 2015, 2, no. 3, 22.

24. A. Anandan, S. Rajendran, J. Sathiyabama and D. Sathiyaraj, Influence of some tablets on corrosion resistance of orthodontic wire made of SS 316L alloy inartificial saliva, Int. J. Corros. Scale Inhib., 2017, 6, no. 2, 132-141. doi: 10.17675/2305-6894-2017-6-2-3 
25. D. Lakshmi, J. Sathiyabama and S. Rajendran, The inhibition effect of $o$-nitrophenol and $\mathrm{Zn}^{2+}$ system on corrosion of aluminium, Int. J. Corros. Scale Inhib., 2017, 6, no. 3, 240 261. doi: 10.17675/2305-6894-2017-6-3-2

26. S. Rajendran, B.V. Apparao and N. Palaniswamy, Bull. Electrochem., 1997, 13, no. 12, 441-447.

27. D.B. Powell and A. Woollins, Vibrational spectra of metal, formamide complexes, Spectrochim. Acta, Part A, 1985, 41, no. 9, 1023-1033. doi: 10.1016/05848539(85)80001-5

28. B.S. Devi and S. Rajendran, Int. J. Chem. Sci. Technol., 2011, 1, 79-87.

29. M. Sangeetha, S. Rajendran, J. Sathiyabama, T. Umasankareswari, A. Krishnaveni and R.M. Joany, Int. J. Nano Corr. Sci. Eng., 2015, 2, no. 3, 14.

30. P.N. Devi, J. Sathiyabama and S. Rajendran, Study of surface morphology and inhibition efficiency of mild steel in simulated concrete pore solution by lactic acid- $\mathrm{Zn}^{2+}$ system, Int . J. Corros. Scale Inhib., 2017, 6, no. 1, 18-31. doi: 10.17675/2305-6894-2017-6-1-2 